SMART Journal, Volume 6, No. 2, August 2020, Page 98- 107

ISSN Cetak : 2356-2048

ISSN Online : 2356-203X

\title{
TEACHING READING COMPREHENSION THROUGH DIRECT METHOD TO THE EIGHTH GRADE STUDENTS OF THE STATE JUNIOR HIGH SCHOOL 44 OF PALEMBANG
}

\author{
Sri Yuliani \\ Faculty of Teacher Training and Education of Muhammadiyah University Palembang \\ Email Correspondence: sriyulianihamzah@yahoo.co.id
}

\begin{abstract}
The objective of this research was to find out whether it is effective to teach reading comprehension through direct method to the eighth grade students. This is a quasi -experimental study. The population of this study was eighth grade students of the State Junior High School 44 of Palembang. In collecting the data, the researcher gave the test. From the result of the research, it found that the students' score in experimental group and control group were 4.46,2 which value of t-obtained was higher than t-table. In other words, teaching reading comprehension through direct method was effective.
\end{abstract}

Keywords: teaching, reading comprehension, direct method

\section{INTRODUCTION}

Reading is about understanding written text. It is a complex activity that both perception and thought. Next, reading is one of the complex ways in learning English. It is a kind of activity to comprehend the writer's idea or the way the writer communicates with the readers by way of the written or printed words. It is clear that reading is one of the skills in learning language, plays a vital to learning success. By reading a lot, students can learn and gain abundant information.

In learning reading comprehension, the students may face some problems namely, in speed reading, their eyes keep wandering back and forth over the page, low motivation, and limited vocabulary as they are for comprehension (Price, 2009). Based on the observation at Junior High School 44 of Palembang, She found that most students got difficulties in learning reading. When the

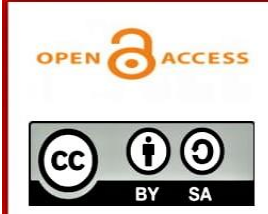

Creation is distributed under the Creative Commons License Attribution Share Alike 4.0 International Published in https://ejournal.umpri.ac.id/index.php/smart/index SMART Journal: Journal of English Language Teaching and Applied Linguistics 
Sri...

teacher asked them the meaning of certain words in the text, the students said that they did not know the meaning of the words and also when the teacher asked them to do exercises in the handbook, they couldn't answer the questions correctly related to the text. These made the students not learn reading optimally and also made them felt bored.

In teaching and learning process, there are many reading strategies can be applied to make the students active in doing reading comprehension activity. (Harmer, 2002) states that teaching reading is taught from elementary school to university by using many kinds of methods applied by English teachers.

Based on the explanation above, the researcher would try to get the solution to make the students are easy to understand by choosing a technique in teaching of reading comprehension that is direct Method. It helped the students understand the content of reading materials.

According to Moore (2005: 228), direct method is a systematic teaching or an active teaching, is a teacher-centered, skill building instructional model with the teacher being a major information provider. In addition, The Direct Method is a process of teaching lesson signed by explaining about what they read. This way would make the students more understand in the process of learning.

Based on the background above, the researcher was interested to investigate whether or not it is effective to teach reading comprehension through direct method to the Eighth Grade Students of the State Junior High School 44 of Palembang.

\section{Concept of Teaching}

Teaching is the profession of a teacher. According to Brown (2007: 8), teaching is a guiding and facilitating learning, enabling the students to learn, setting condition for learning. Next, according to Slameto (2010: 30) teaching is guidance of learning. It is clear that the teaching is an activity between teacher 
Teaching...

and students that teacher can give knowledge and guide the students in teaching and learning process so that they are related each other.

\section{Concept of Reading}

Reading is a mental process or an activity of processing and understanding information from printing texts. Reading is not only relied much on our knowledge of text each words in a text but also to digest the content offered in a text. Next, reading is a process employed by an individual in order to understand what an author says (Brown, 1994: 271). It is clear that reading is a process between the reader and the text which associated with meaning and the reader use strategy to determine what the meaning is.

\section{Concept of Reading Comprehension}

Snow (2012: 11) states that reading comprehension as the process of simultaneously extracting and constructing meaning through interaction and involvement with written language. According to Zwier (2004: 99), reading comprehension is a three-stages process. Each stage includes questioning, and each questioning made by the reader itself. First, the reader must ask good questions before they read as preparing to find and store the information. Second, during reading the readers must ask questions which are about the main ideas and the purposes of the reading content it. Third, after reading, the readers must ask questions more to further organize what they are learning.

\section{Concept of Direct Method}

Direct method in teaching a language is directly establishing an immediate and audio visual association between experience and expression, words, and phrases, idioms, and meanings, rules, and performances through the teachers' body and mental skills without any help of the learner's mother tongue. According to Moore (2000: 228), direct method is a systematic teaching or active teaching, is a teacher-centered, skill building instructional model with the teacher being a major information provider. 
Furthermore, Norland \& Terry (2006: 5) state that direct method was often develops around set a picture that portrays life in the country of the target language. From the beginning, students are taught, and must respond, in the target language. Besides pictures, real and simple actions are used to get across meaning. Lesson often focuses around question and answer dialogues. Correct pronunciation is also emphasized, but correct structure is not. Students may also read passages for information about the target language. Teacher may ask questions about the reading to check comprehension, but it is never translated.

\section{The Benefit of Using Direct Method}

In Teaching Reading Comprehension in Direct Method, there are two benefits of using Direct Method.

1. This is a quick way for students to learn basic conversation skill because the method lays more emphasis on oral work. That ensures good pronunciation to the learners.

2. Teaching Direct Method is helpful to teachers who do not know their students first language because the teacher proceeds from particular to general and form concrete to abstract (Norland and Terry, 2006: 6).

Teaching and learning procedure for experimental group through direct method is as follow:

\section{Pre-Activities}

a. Teacher shows a picture about the material in the book before they learn

b. Teacher asks to the students what about the material like the picture

c. Teacher gives the students to answer the teacher's question about the material

\section{Whilst-Activities}

a. Teacher asks the students open their book about the material

b. Teacher asks the students to read and comprehend about the story in the book

c. Teacher asks for the students about what the topic after the students read.

d. Teacher describes the picture best on the material in the book 
e. Teacher gives the students to find the difficult word about the material and the students translate about the material

f. Teacher asks the students to read of the material in the book in front of class one by one

g. Teacher gives additional about the material in the book

\section{Post-Activities}

After doing the activities, the teacher make summary of the text in the book.

\section{RESEARCH METHOD}

Method is a way in doing something. In this research, the researcher used the quasi-experimental design. According to Frankel et,al (2012,p.275), quasiexperimental design do not include the use of random assignments. This quasiexperimental design provided a pretest to both groups, the treatment activity with experimental group only, and a posttest assess the difference between two groups.

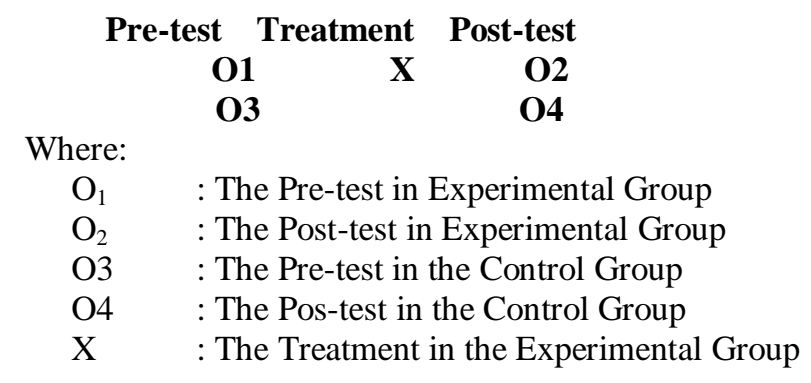

\section{Diagram 1 Pretest and Posttest Design}

There are two kinds of research variables; they are dependent and independent variable. In this research, direct method as the independent variable, and students' score of reading comprehension as dependent variable.

In this research, the population is all of the eighth grade students of the state Junior High School 44 of Palembang with the total number of 332 students. While, the sample of this research was taken two classes, namely: class 
Sri...

VIII7 who were classified as experimental class, and class VIII 3 who were classified as control group with the total number of 74 students by using purposive non random sampling. Purposive sampling is the way to take sample because of the specific purpose (Arikunto, 2010, 183).

In this research, the instrument that used in collecting the data is a test. There were 20 items and the type of test is multiple choices. There were two kinds of test to measure the students' achievement in their reading comprehension; they are pre-test and post-test.

For analyzing the data, it was obtained through the test that analyzed by using Statistical Package for Social Science (SPSS) 16.0 programs. The researcher used paired sample t-test to find out whether or not there was a significant difference in score between the pretest and the posttest in the experimental group and control group. Furthermore, independent sample t-test was used to find out whether or not there was a significant difference in students' posttest in experimental and control group.

\section{RESULT AND DISCUSSION}

\section{The Result of Students' Pretest and Posttest in Experimental Group}

The students who participated in the pretest was 37 students. From the result of the study, the highest score in pretest was in 85and the lowest score was 30 .The mean was 67.70 , the median was 70.00 , and the mode was 70 meanwhile the students who participated in posttest was 37 students. The highest score in posttest was 80 and the lowest score was 70 . The mean was 80.81the median was 80.00 , and the mode was 75 . 
Table 1 T-test Calculation (SPSS 16.0 Program)

\begin{tabular}{|c|c|c|c|c|c|c|c|c|}
\hline & \multicolumn{5}{|c|}{ Paired Differences } & \multirow[b]{3}{*}{$\mathrm{t}$} & \multirow[b]{3}{*}{$\mathrm{df}$} & \multirow{3}{*}{$\begin{array}{l}\text { Sig. (2- } \\
\text { tailed) }\end{array}$} \\
\hline & \multirow[b]{2}{*}{ Mean } & \multirow{2}{*}{$\begin{array}{l}\text { Std. } \\
\text { Deviati } \\
\text { on }\end{array}$} & \multirow{2}{*}{$\begin{array}{l}\text { Std. } \\
\text { Error } \\
\text { Mean }\end{array}$} & \multicolumn{2}{|c|}{$\begin{array}{c}95 \% \text { Confidence } \\
\text { Interval of the } \\
\text { Difference }\end{array}$} & & & \\
\hline & & & & Lower & Upper & & & \\
\hline $\begin{array}{ll}\text { Pair } & \text { Posttestexpr - } \\
1 & \text { Pretestexpr }\end{array}$ & 13.108 & 13.761 & 2.262 & 8.520 & 17.696 & 5.794 & 36 & .000 \\
\hline
\end{tabular}

This research used paired sample test which paired post-test score with pre-test score. From the data calculation t-test, it was found the average scores' of the students in the pre-test and post-test were 13.108 with the standard error mean 2.262, while the standard deviation was 13.761, and the upper scores was 17.696 in the level $95 \%$ confidence interval of the differences. The degree of freedom (df) 31 .

The table above showed that t-obtained was 5.794 at the significant level of p>0.05 in 2-tailed and the degree of freedom (df) was 36, the critical value was 0.279. If t-obtained was higher than critical value of t-table $(5.794>0.279)$, (Ha) was accepted and null hypothesis (Ho) were rejected. It can be stated that teaching reading comprehension through direct method was effective.

\section{The Result of Students' Pretest and Posttest in Control Group}

The students who participated in the pre-test were 37 students .Based on the result of the research, the highest score was 85 students and the lowest score was 30. The mean score in control group was 62.30, the median was 65.00 and the mode was 70. While, the highest score of posttest in control group was 85, and the lowest score was 60 . The mean was 72.84 , the median was 75.00 , and the mode was 80 . 
Sri...

Table 2 Paired sample T-test Calculation

\begin{tabular}{|c|c|c|c|c|c|c|c|c|}
\hline & \multicolumn{5}{|c|}{ Paired Differences } & \multirow[b]{3}{*}{$\mathrm{t}$} & \multirow[b]{3}{*}{$\mathrm{df}$} & \multirow{3}{*}{$\begin{array}{l}\text { Sig. }(2- \\
\text { tailed) }\end{array}$} \\
\hline & \multirow[b]{2}{*}{ Mean } & \multirow{2}{*}{$\begin{array}{c}\text { Std. } \\
\text { Deviation }\end{array}$} & \multirow{2}{*}{$\begin{array}{l}\text { Std. } \\
\text { Error } \\
\text { Mean }\end{array}$} & \multicolumn{2}{|c|}{\begin{tabular}{|c|}
$95 \%$ Confidence \\
Interval of the \\
Difference \\
\end{tabular}} & & & \\
\hline & & & & Lower & Upper & & & \\
\hline $\begin{array}{c}\text { Pair } 1 \text { Posttestcontrol - } \\
\text { Pretestcontrol }\end{array}$ & 10.541 & 19.713 & 3.241 & 3.968 & 17.113 & 3.253 & 36 & .002 \\
\hline
\end{tabular}

From the data calculation of t-test, it was found that the average scores of the students in the pre-test and post-test were 10.541 with the standard error mean was 3.241 , while the standard deviation was 19.713. From the differences of the result, it was found that the lower scores was 3.968 and the upper scores was 17.113 in the level $95 \%$ confidence interval of the differences. The degree of freedom (df) 36.

The table above showed that t-obtained was 3.253 at the significant level of $p<0.05$ in 2tailed and the degree of freedom (df) was 36 , the critical value was 0.279 . If $\mathrm{t}$-obtained was higher than critical value of $\mathrm{t}$-table $(3.253>0.279)$, (Ha) was accepted and null hypothesis (Ho) was rejected. It can be stated that teaching reading comprehension through direct method was effective.

Table 3 T-test Calculation Result of Posttest in the Experimental Group and Control Group Independent Samples Test

\begin{tabular}{|c|c|c|c|c|c|c|c|c|c|}
\hline & \multicolumn{2}{|c|}{\begin{tabular}{|c|} 
Levene's Test \\
for Equality \\
of Variances \\
\end{tabular}} & \multicolumn{7}{|c|}{ t-test for Equality of Means } \\
\hline & \multirow[b]{2}{*}{$\mathbf{F}$} & \multirow[b]{2}{*}{ Sig. } & \multirow[b]{2}{*}{$\mathbf{t}$} & \multirow[b]{2}{*}{ df } & \multirow{2}{*}{$\begin{array}{l}\text { Sig. (2- } \\
\text { tailed) }\end{array}$} & \multirow{2}{*}{$\begin{array}{c}\text { Mean } \\
\text { Difference }\end{array}$} & \multirow{2}{*}{$\begin{array}{l}\text { Std. Error } \\
\text { Difference }\end{array}$} & \multicolumn{2}{|c|}{$\begin{array}{l}95 \% \text { Confidence } \\
\text { Interval of the } \\
\text { Difference }\end{array}$} \\
\hline & & & & & & & & Lower & Upper \\
\hline $\begin{array}{l}\text { Equal } \\
\text { variances } \\
\text { assumed }\end{array}$ & 6.412 & .014 & 4.462 & 72 & .000 & 7.973 & 1.787 & 4.411 & 11.535 \\
\hline $\begin{array}{l}\text { Equal } \\
\text { variances not } \\
\text { assumed }\end{array}$ & & & 4.462 & 68.218 & .000 & 7.973 & 1.787 & 4.408 & 11.538 \\
\hline
\end{tabular}


The result of independent sample t-test showed the value of t-obtained was 4.462 at the significant level $p<0.05$ for two tailed and degree of freedom was 72, t-table was 0.279 . Since the value of t-obtained was higher than t-table, so that the null hypothesis (Ho) was rejected and alternative hypothesis (Ha) was accepted. So, it was evident that there was a significant difference between the students' reading comprehension who was taught through direct method and those who were taught through conventional method.

\section{CONCLUSIONS}

Based on the result of analyzing the data, there were some conclusions which could be described from the scores that were found, the result of statistical analysis between experimental and control group (t-obtained) should be higher than t-table (0.279). Furthermore, the result of the students' score in control group and experimental group (value of t-obtained) were 4.462. Since the value of t-obtained was higher than t-table, so that the null hypothesis was rejected and alternative hypothesis was accepted. It could be stated that teaching reading comprehension through direct method to the eighth grade students at the state junior high school number 44 of Palembang was effective.

\section{REFERENCES}

Arikunto, S. (2006). Procedure Penelitian Suatu Pendekatan Praktik, Jakarta: Rineka Cipta.

Brown, H. D. (1994). Teaching by Principles and Interactive : An Interactive Approach to Language Pedagogy. New Jersey: Prentice Hall.

Cresswell, J. W. (2005).Educational Research: Planning, Conducting, and Evaluating Quantitative and Quantitative Research $2^{\text {nd }}$ Ed. New Jersey: Pearson Education, Inc.

Frankel\&Wallen.(2012). How to Design nd Evaluate Research in Education. New York: The McGraw-Hill Companies. 
Sri...

Harmer, J. (2007). The Practice of English Language Teaching. Essex: Pearson Education Limited.

Moore, K. D. (2005). Effective Instructional Strategies: From theory to Practice. SAGE Publications, Inc.:

Norland, L.Deborah and Terry Pruett.(2006). A Kaleidoscope of Models and Strategies for Teaching English to Speakers of Other Language. Sard Wesport: CT Libraries Unlimited/ Teacher Ideas Press.

Price, S. (2009). Overcoming Reading Problem. Monas University. Retrieved from htttp://www.Monas.Edu.Au /Iis/IIonlineeeading/reading-problemson /L.xml. Assessed on November 15, 2019.

Slameto.(2010). Belajar dan Faktor-Faktor Mempengaruhi. Jakarta: Rineka Cipta.

Snow, E C.(2002). Reading for Understanding Toward an R\&D Program in Reading Comprehension. Pittsburgh: RAND Reading Study.

Zwiers, Jeff. (2004). Building Reading Comprehension Habits in Grades 6-12. Menlo Park Publication: California, USA. 